\title{
Expansion or Incubation? Which is Better to Manipulating Stem Cells for Improving the Effects of Umbilical Cord Blood Transplantation
}

\section{Yang-Yang Lei}

Academy of Military Medical Sciences

Lu Wang

Academy of Military Medical Sciences

Lei Deng

Academy of Military Medical Sciences

Yang Yang

Zhengzhou University First Affiliated Hospital

Ang Zhang

Academy of Military Medical Sciences

\section{Shao-Hong Chang}

5th Medical Center of Chinese PLA General Hospital

Wen-Ming Hua

5th Medical Center of Chinese PLA General Hospital

\section{Bin Rong}

JOINN laboratories

Mei Guo

5th Medical Center of Chinese PLA General Hospital

Hui-Sheng Ai

5th Medical Center of Chinese PLA General Hospital

Kai-Xun Hu ( 942056176@qq.com )

5th Medical Center of Chinese PLA General Hospital https://orcid.org/0000-0003-4994-0530

\section{Primary research}

Keywords: stem cell expansion, bone marrow homing ability, umbilical cord blood, transplantation

Posted Date: June 1st, 2020

DOI: https://doi.org/10.21203/rs.3.rs-30877/v1

License: (c) (i) This work is licensed under a Creative Commons Attribution 4.0 International License. Read Full License 


\section{Abstract}

Background: Delayed hematopoietic recovery was one of the factors that limited the clinic application of umbilical cord blood (UCB) transplantation. Two different methods of overcoming the limitation were evaluated by this systematic review and meta-analysis. One strategy was to expand UCB unit ex vivo for increasing cell dose and another strategy was to incubate UCB unit with small molecules in vitro for enhancing bone marrow (BM) homing ability.

Methods: Relevant literatures were collected from 2000 to 2020 by searching the databases of PubMed, Medline, and EMBASE. A total of 15 studies that met the inclusion criteria were included in the meta-analysis.

Results: Similar clinical effects including neutrophil recovery $(P=0.308)$, platelet recovery ( $P=0.4754)$, and 100-day survival $(P=0.4216)$ between two methods were observed. Faster neutrophil recovery was associated with higher infused total nucleated cells (TNCs) $\left(R^{2}=0.4526 P<0.05\right)$ and higher infused $C D 34+$ cells $\left(R^{2}=0.9777 P=0.095\right)$ in patients of expansion group and incubation group, respectively.

Conclusion: Although the treatment outcomes by using expanded stem cells were getting better all these years with fast development of cell culture techniques according to our cumulative meta-analysis. It seems the application of incubation procedure was safer and more convenient than expansion regarding to their similar clinic effects. This study was registered at RROSPERO (Registration no. CRD42020149750).

\section{Background}

The field of umbilical cord blood banking and transplantation has grown exponentially over the last 25 years. Receiving umbilical cord blood transplantation (UCBT) may be a good choice for hematological malignancy patients when the HLA-matched donors are not available or the transplantations are urgently needed [1]. Despite the encouraging results have been gotten from pediatric patients, several disadvantages of UCBT have emerged for adults. For instance, the high risk of graft failure, delayed hematopoietic recovery, and poor immune reconstruction, delays the pace of UCBT clinical application. The sparsely-numbered of stem cells and mature immune cells in a single UCB unit could be an explanation for these shortcomings [2]. To make UCBT as effective as bone marrow transplantation and peripheral blood transplantation, different stem cell manipulation methods have been used.

Expanding UCB cells in vitro for several days is a widely-used method to increase the numbers of TNCs and CD34 + stem cells. Theoretically, with a perfect expanded process, an ideal treatment outcome can be achieved in a single UCB unit transplantation. And double UCB units' transplantations have paved safer ways for the applications of UCB cell expansion products by avoiding the risks of cell culture or graft failures in single unit UCBTs $[3,4]$. Another way is to enhance the UCB stem cells' bone marrow homing ability by incubating them with small molecules within a short time. The neutrophil and platelet recovery can be accelerated and the survival can be prolonged with the application of incubated products, although the UCB doses are not altered during manipulation processes [5]. Other methods have also been studied in varying extent, such as the co-infused HLA-mismatched UCB expansion products [6, 7], intra-BM injected donor cells, and co-infused donor T cells [8, 9]. Notably, only the first two methods were evaluated in our study, whereas the rest were beyond the scope of our research objects. The similarities and differences between two kinds of manipulation will be studied in our systematic review and meta-analysis.

\section{Method}

This study had been registered at http://www.crd.york.ac.uk/prospero/ (Registration no. CRD42020149750). And the study were designed by the statement of preferred reporting items for systematic reviews and meta-analyses (PRISMA) [10].

Search strategy

The PubMed, Medline and EMBASE database were searched for the period from 2000 to 2020. We used the searching terms "improve engraftment" and "ex vivo expansion or incubation" in combination with "umbilical cord blood" and "transplantation".

Study selection

Since no proper clinic trial that directly compared these two methods was available, we therefore included studies that evaluated one of the two methods provided they had the same inclusion and exclusion criteria. The enrolled studies must met the following criteria: (a) the UCB units chosen for manipulation were required to be $\geq 4 / 6$ human leukocyte antigen (HLA)-allele matched with the recipients; (b) in double UCB units' transplantation cases, the manipulated UCB unit must be infused to patients together with the unmanipulated one at the same time (twenty-five unmatched patients in one study [11] were excluded while the other twelve remained); (c) the neutrophil recovery time need to be accurate and available in articles, with or without the historical control data. (d) no duplicate reported results.

End points 
Primary endpoints of this study were the neutrophil and platelet recovery time after UCBT. Secondary endpoints were 100-day survival rate. The relationship between infused cell doses with transplantation outcomes were also evaluated.

Quality assessment

The quality of included studies were assessed by reporting the key points of the clinic trials' designs [12]. Such as the number of infused UCB units per patient; the stem cell selection procedures before expansion ex vivo; cytokines and mediums that were used for manipulation; days required for expansion or incubation; number of patients; the medium weight and age of patients and the conditioning methods.

\section{Statistical analysis}

The outcomes of historical controls were not available in some studies. To be more accurate and avoiding published bias, we used the STATA version 12.0 to make a single-arm meta-analysis. Outcomes were compared using the reported means and standard deviations (SD). If the data was not available in literature, we would ask for it from the author directly. And the data could also be estimated from the reported median and ranges without author's response [13]. A random effects model will be chosen with the $I^{2}>50 \%$.

\section{Results}

Literature search

The procedure of study selection was presented in Fig. 1. A total of fifteen clinic trials were included at last. Twelve of them were designed to study the effects of stem cells expansion in vitro while the other three were focusing on the incubation of stem cells ex vivo.

Study characteristics

Fourteen phase I/II clinic trials [11, 14-26] and one phase II/III clinic trials [27] were included and their characteristics were presented in Table 1. One study [14] had a randomized control group while fourteen studies [11, 15-27] were single arm clinic trials for using historical controls. It's worth mentioning that the historical controls were well matched for transplantation conditioning, disease status, age, graft size, HLA matching and performance score criteria. Children and adult patients were both included in eight studies [11, 15-17, 21, 24, 26, 27] while six studies [18-20, $22,23,25]$ only focused on adult patients. Twelve studies [11, 15, 17, 18, 20-27] used myeloablative conditioning whereas only one study [19] used nonmyeloablative regimens, and two $[14,16]$ used both of them. One manipulated UCB unit and one unmanipulated unit were co-infused to patients in eleven studies [14, 16-25]. Four studies [11, 15, 26, 27] used only one manipulated UCB unit. Only one study didn't select stem cells with CD34 + or CD133 + biomarker before expansion in vitro [18]. 
Table 1

Characteristics of studies included in the meta-analysis.

\begin{tabular}{|c|c|c|c|c|c|c|c|}
\hline Study & Phase & $\begin{array}{l}\text { Patients } \\
\text { (experimental) }\end{array}$ & $\begin{array}{l}\text { Patients } \\
\text { (control) }\end{array}$ & Age & Preconditioning & CBUs & $\begin{array}{l}\text { Expanded cell } \\
\text { type }\end{array}$ \\
\hline 2002 Shpall & I & 37 & - & children/adult & MA & 1 & CD34+ \\
\hline 2007 Lima & $\mathrm{I} / \mathrm{II}$ & 24 & 24 & - & NMA/MA & 2 & CD133+ \\
\hline 2008 Lima(BMT) & $\mathrm{I} / \mathrm{II}$ & 10 & - & children/adult & MA & 1 & CD133+ \\
\hline 2008 Lima(Blood) & $\mathrm{I} / \mathrm{II}$ & 35 & 36 & children/adult & NMA/MA & 2 & CD133+ \\
\hline 2010 Delaney & 1 & 10 & 20 & children/adult & MA & 2 & CD34+ \\
\hline 2012 Lima & I & 31 & 80 & adult & MA & 2 & unselected \\
\hline 2013 Delaney & I & 23 & 40 & children/adult & MA & 2 & CD34+ \\
\hline 2014 Horwitz & I & 11 & 17 & adult & MA & 2 & CD133+ \\
\hline 2016 Wagner & $\mathrm{I} / \mathrm{II}$ & 17 & 111 & children/adult & MA & 2 & CD34+ \\
\hline 2017 Anand & $\|$ & 19 & 86 & adult & MA & $1 / 2$ & CD133+ \\
\hline 2018 Stiff & II/III & 101 & 295 & children/adult & MA & 1 & CD133+ \\
\hline 2018 Horwitz & $\mathrm{I} / \mathrm{II}$ & 36 & 146 & children/adult & MA & 1 & CD133+ \\
\hline 2013 Brunstein & I & 29 & - & adult & NMA & 2 & - \\
\hline 2015 Popat & I & 22 & 31 & adult & MA & 2 & - \\
\hline 2013 Cutler & I & 21 & 53 & adult & MA & 2 & - \\
\hline
\end{tabular}

Procedures of stem cell manipulation

The manipulation procedures of UCB units have been summarized in Table 2. The effects of expansion or incubation determined the cell status such as cell number, cell viability and cell type. And the outcomes of UCBT were closely associated with the cell status. Most of the expansion studies added regular cytokines into their cell culture systems including stem cell factor (SCF), FMS-like tyrosine kinase 3 ligand (Flt3L), [18]megakaryocyte growth and development factor (MGDF) were also used in early studies [11, 14]. However, the effects of regular cytokines cultured stem cells on speeding up time to neutrophil recovery were controversial [28-31]. Some new small molecules or feeder cell layers were added into the cell culture system to augment the effects of regular cytokines in later expansion clinic trials [18, 24]. 
Table 2

Details of manipulation methods.

\begin{tabular}{|c|c|c|c|}
\hline Study & Cytokines & Additional intervention & Culture time \\
\hline 2002 Shpall & SCF GCSF MGDF & - & $10 \mathrm{~d}$ \\
\hline 2007 Lima & SCF GCSF TPO & - & $14 \mathrm{~d}$ \\
\hline 2008 Lima(BMT) & SCF TPO FIt3L IL-6 & 5UM TEPA & $21 \mathrm{~d}$ \\
\hline 2008 Lima(Blood) & SCF GCSF TPO & - & $14 \mathrm{~d}$ \\
\hline 2010 Delaney & SCF TPO FIt3L IL-6 IL-3 & Delta $1^{\text {ext }-\lg G}$ & $16 \mathrm{~d}$ \\
\hline 2012 Lima & SCF TPO FIt3L IL-6 GCSF & MSC & $14 \mathrm{~d}$ \\
\hline 2013 Delaney & $\mathrm{nr}$ & Delta1 ${ }^{\text {ext }-\lg G}$ & $\mathrm{nr}$ \\
\hline 2014 Horwitz & SCF TPO Flt3L IL-6 & $2.5 \mathrm{mM}$ NAM & $21 \mathrm{~d}$ \\
\hline 2015 Forcade & SCF FLT3L TPO GCSF & - & $\mathrm{nr}$ \\
\hline 2016 Wagner & SCF TPO FIt3L IL-6 & SR-1 & $15 \mathrm{~d}$ \\
\hline 2017 Anand & SCF TPO FIt3L IL-6 & $2.5 \mathrm{mM}$ NAM & $21 d$ \\
\hline 2018 Stiff & SCF TPO FIt3L IL-6 & 5UM TEPA & $21 d$ \\
\hline 2018 Horwitz & SCF TPO FIt3L IL-6 & $2.5 \mathrm{mM}$ NAM & $19-23 d$ \\
\hline 2013 Brunstein & - & $1 \mu \mathrm{g} / \mathrm{m} \mathrm{C3aL}$ & $15 \min$ \\
\hline 2015 Popat & - & $1 \mathrm{mM} \beta$-fucose & $30 \mathrm{~min}$ \\
\hline 2013 Cutler & - & 10uM PEG2 & $60 \mathrm{~min} / 120 \mathrm{~min}$ \\
\hline
\end{tabular}

As for incubation studies, the cytokines mentioned above were not necessary. Three kinds of small molecules were used to improve the stem cells' homing ability by incubating with UCB units from fifteen minutes to two hours. And the incubating time was vital. PGE2 could contribute to a better clinic outcome through two hours' incubation with stem cells, however, the effects were not good as only one hours' incubation. So the data of patients in one hours' incubation group were not evaluated in our study.

Comparing the differences between two methods, the processes of UCB expansion often cost lots of materials including serum free mediums and cytokines. All these additive is known to be expensive and could increase the financial burden on patients at last. There is also high risk of contamination during the several days of cell culture. In fact, the contamination cases are often reported in expansion studies [22, 24]. As a result, the incubation procedures seemed to be cheaper, safer and more convenient in accelerating neutrophil recovery.

Described in Table 3, expansion procedures yielded an average of 1.7-854 fold expansion (FE) in TNCs and 2.2-330 FE in CD34 + cells. Manipulated UCB units had more TNC numbers than unmanipulated units. The difference was larger for CD34 + cells. As a comparison, incubating did not alter the cell numbers. Much more TNCs and CD34 + cells thus could be infused to patients after expansion manipulation. But can they lead to a better outcome in UCB transplantation?

Neutrophil recovery

The medium time and range of neutrophil recovery can be acquired from fifteen studies [11, 14-27] and the data of randomized or historical controls are available in ten studies. Although the evaluation including data from both treatment and control group is the gold standard for metaanalysis, more published bias will emerge with only these ten studies included. To make a more rounded analysis, we discreetly enrolled all fifteen studies including five studies that didn't have control groups and regarding all of them as single-arm clinic trials. And the other outcomes will be evaluated in the same way.

The overall effect size (ES) of neutrophil recovery in expansion studies and incubation studies was 17.77 (95\% Cl 14.02-21.51) and 16.87 (10.04-23.70), respectively (Fig. 2A-B). No significant difference was found $(P=0.308)$. Expansion or incubation, compared with control group, could both accelerate the neutrophil recovery. But it seems the time to neutrophil recovery remained the same even these patients in expansion studies received much more TNCs and CD34 + cells.

Platelet recovery 
The Overall ES was $47.83(95 \% \mathrm{Cl} 38.80-56.86)$ for expansion manipulation group and $46.03(95 \% \mathrm{Cl} 38.58-53.48)$ for incubation manipulation group. (Fig. 2C-D). No significant difference between two kinds of manipulation was found $(P=0.4754)$. The result revealed that the patient's platelet recovery time in expansion groups was barely shortened after being infused so many expanded UCB stem cells comparing with the patients in incubation group.

100-day survival

Based on existing studies, eight expansion studies and two incubation studies reported the data of 100-days survival rate. The overall ES of 100days survival rate was $0.91(95 \% \mathrm{Cl} 0.84-0.97)$ for the expansion studies and $0.89(95 \% \mathrm{Cl} 0.79-0.97)$ for the incubation studies. No significant difference between two manipulation procedures was found $(P=0.4216)$ (Fig. 3).

Relationship between cell dose and outcomes

The association between UCB cell dose and hematopoietic recovery was assessed by a list of studies [32-34]. The positive correlations between the two factors were reported, although not all of them were significant. This was further confined by a systematic review [35]. In our enrolled studies, Wagner et al, de Lima et al, and Horwitz et al reported the strong correlation between neutrophil recovery and infused TNC or CD34 + cell dose $[18,22,24]$. A moderate negative association between total infused TNC dose and neutrophil recovery in expansion studies was revealed $\left(R^{2}=0.4526 \mathrm{P}<0.05\right)$. The total TNC dose was unrelated to the neutrophil recovery in incubation studies. We also found a moderate correlation between CD34 + cell dose and neutrophil recovery in incubation studies $\left(R^{2}=0.9777 P=0.095\right)$, however, not in expansion studies. Unlike the reported results in other reviews, no observable correlation between platelet recovery time and cell dose was revealed.

Mechanism involved in manipulation

The function and cell number of UCB units were believed to be altered by the small molecules and feeder cells. Not surprising, the involved intrinsic and extrinsic signals were different between two methods. And some common signals shared between expansion and incubation were also revealed (Fig. 4).

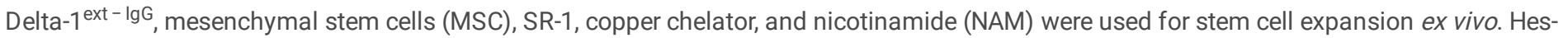
1 ,known as a Notch transcriptional target, could preserve the long-term reconstituting hematopoietic activity and the self-renewal ability of stem cells [36-40]. And the clinic trials could be able to be conducted with the application of immobilized Delta-1 ligand [41]. MSCs have been widely used for stem cell expansion as feeder layers [42-45]. As for the mechanisms that may be responsible for MSC's regulating effects, no all agreed explanation was achieve. Y. K. Jang et al considered that a list of cytokines including IL-1a/ $\beta \square$ IL-6, IL-7, leukemia inhibitory factor (LIF), FL, TPO, SCF, C-kit, macrophage colony stimulating factor (M-CSF), and GM-CSF that secreted by MSCs could support the ex vivo expansion of stem cells [46]. High level of SDF-1a, an effective chemotactic factor which contributes to stem cell bone marrow homing, was also detected in the supernatants of UCB expansion system [47]. SR-1 could inhibit differentiation and promote proliferation of stem cells by antagonizing aryl hydrocarbon receptor (AhR) [48-50]. Copper chelator could reduce the intracellular copper content of stem cells by decreasing mitochondrial membrane potential, which lead to a better expansion result [51-54]. NAM could reduce the p21 expression and promote the proliferation of stem cells as one of the noncompetitive inhibitors of SIRT1. The homing ability was also increased by the regulation of CXCR4 downstream signaling pathways $[55,56]$. Prostaglandin E2 (PGE2), C3a, and fucosylation were used for short time incubation to increase the bone marrow homing ability. PGE2 could upregulate the expression of Cox1 and Cox2, which contributes to stem cell proliferation [57]. The homing ability of stem cells was also increased by up-regulating CXCR4 after PGE2 incubation. Additionally, survivin, as the inhibitor of intracellular active caspase-3, was activated by PGE2 and thus suppressed the apoptosis of stem cells [58-60]. C3a-C3aR axis plays a functional role in enhancing marrow homing ability of stem cells by increasing their responsiveness to SDF-1. And the matrix metalloproteinase-9 (MMP-9) was involved in this process [61, 62]. Treatment of stem cells with the enzyme fucosyltransferase-VI and guanosine diphosphate fucose could increase the cell-surface sL $e^{X}$ determinants, further enhancing homing ability of stem cells through a better P- and E-selectin binding capacity [63-65].

Ongoing clinic trials

There are a total of seven clinic trials ongoing and all of them are using ex vivo expansion methods (NCT01590628, NCT01690520, NCT02730299, NCT03173937, NCT03441958, NCT04103879, NCT03913026). No clinic trial about incubation is available. Obviously, clinicians prefer expansion to incubation. Their belief might rely on the continuous development of cell culture techniques and application of effective new molecules, such as UM171 [79, 80]. Indeed, a trend toward better treatment outcomes along with the development of cell ex vivo culture system was emerged according to our cumulative meta-analysis (Fig. 5). But more clinic trials should be completed to prove the advantage of expansion methods. 
Table 3

Expanded and infused cell dose.

\begin{tabular}{|c|c|c|c|c|c|c|c|c|}
\hline Study & $\begin{array}{l}\text { TNC EF } \\
\text { medium } \\
\text { and } \\
\text { range }\end{array}$ & $\begin{array}{l}\text { CD34+ } \\
\text { EF } \\
\text { medium } \\
\text { and } \\
\text { range }\end{array}$ & $\begin{array}{l}\text { Infused } \\
\text { manipulated } \\
\text { TNC }\end{array}$ & $\begin{array}{l}\text { Infused } \\
\text { manipulated } \\
\text { CD34+ }\end{array}$ & $\begin{array}{l}\text { Infused } \\
\text { unmanipulated } \\
\text { TNC }\end{array}$ & $\begin{array}{l}\text { Infused } \\
\text { unmanipulated } \\
\text { CD34+ }\end{array}$ & $\begin{array}{l}\text { Infused total } \\
\text { TNC }\end{array}$ & $\begin{array}{l}\text { Infused total } \\
\text { CD34+ }\end{array}$ \\
\hline 2002 Shpall & $\begin{array}{l}56(1.03- \\
278)\end{array}$ & $\begin{array}{l}4.0(0.1- \\
20.0)\end{array}$ & $\mathrm{nr}$ & $\mathrm{nr}$ & $\mathrm{nr}$ & $\mathrm{nr}$ & $0.99 \times 107 / \mathrm{Kg}$ & $1.04 \times 105 / \mathrm{Kg}$ \\
\hline 2007 Lima & $\begin{array}{l}26(0.44- \\
275)\end{array}$ & $\begin{array}{l}2.2(0- \\
18)\end{array}$ & $\mathrm{nr}$ & $\mathrm{nr}$ & $\mathrm{nr}$ & $\mathrm{nr}$ & $3.6 \times 107 / \mathrm{Kg}$ & $1.6 \times 105 / \mathrm{Kg}$ \\
\hline $\begin{array}{l}2008 \\
\text { Lima(BMT) }\end{array}$ & $\begin{array}{l}161(2- \\
620)\end{array}$ & 2.26 & $\mathrm{nr}$ & $\mathrm{nr}$ & $\mathrm{nr}$ & $\mathrm{nr}$ & $1.8 \times 107 / \mathrm{Kg}$ & $1.5 \times 105 / \mathrm{Kg}$ \\
\hline $\begin{array}{l}2008 \\
\text { Lima(Blood) }\end{array}$ & $\begin{array}{l}23(0.44- \\
275)\end{array}$ & $\begin{array}{l}2.3(0- \\
957)\end{array}$ & $\mathrm{nr}$ & $\mathrm{nr}$ & $\mathrm{nr}$ & $\mathrm{nr}$ & $3.5 \times 107 / \mathrm{Kg}$ & $1.8 \times 105 / \mathrm{Kg}$ \\
\hline $\begin{array}{l}2010 \\
\text { Delaney }\end{array}$ & $\begin{array}{l}\text { 645(192- } \\
2161)\end{array}$ & $\begin{array}{l}140(36- \\
688)\end{array}$ & $4.6 \times 107 / \mathrm{Kg}$ & $60.3 \times 105 / \mathrm{Kg}$ & $3.3 \times 107 / \mathrm{Kg}$ & $2.4 \times 105 / \mathrm{Kg}$ & $7.9 \times 107 / \mathrm{Kg}$ & $62.7 \times 105 / \mathrm{Kg}$ \\
\hline 2012 Lima & $\begin{array}{l}12.2(1.0- \\
29.8)\end{array}$ & $\begin{array}{l}30.1(0- \\
137.8)\end{array}$ & $5.84 \times 107 / \mathrm{Kg}$ & $9.5 \times 105 / \mathrm{Kg}$ & $2.5 \times 107 / \mathrm{Kg}$ & $8.6 \times 105 / \mathrm{Kg}$ & $8.34 \times 107 / \mathrm{Kg}$ & $18.1 \times 105 / \mathrm{Kg}$ \\
\hline $\begin{array}{l}2013 \\
\text { Delaney }\end{array}$ & $\mathrm{nr}$ & $\mathrm{nr}$ & $\mathrm{nr}$ & $\mathrm{nr}$ & $\mathrm{nr}$ & $\mathrm{nr}$ & $\mathrm{nr}$ & $\mathrm{nr}$ \\
\hline $\begin{array}{l}2014 \\
\text { Horwitz }\end{array}$ & $\begin{array}{l}486(171- \\
643)\end{array}$ & $\begin{array}{l}\text { 72(16- } \\
186)\end{array}$ & $3.1 \times 107 / \mathrm{Kg}$ & $35 \times 105 / \mathrm{Kg}$ & $2.6 \times 107 / \mathrm{Kg}$ & $0.7 \times 105 / \mathrm{Kg}$ & $5.1 \times 107 / \mathrm{Kg}$ & $35.7 \times 105 / \mathrm{Kg}$ \\
\hline $\begin{array}{l}2015 \\
\text { Forcade }\end{array}$ & $\mathrm{nr}$ & $\mathrm{nr}$ & $\mathrm{nr}$ & $\mathrm{nr}$ & $\mathrm{nr}$ & $\mathrm{nr}$ & $\mathrm{nr}$ & $\mathrm{nr}$ \\
\hline $\begin{array}{l}2016 \\
\text { Wagner }\end{array}$ & $\begin{array}{l}854(168- \\
2121)\end{array}$ & $\begin{array}{l}330(67- \\
848)\end{array}$ & $5 \times 107 / \mathrm{Kg}$ & $175 \times 105 / \mathrm{Kg}$ & $2 \times 107 / \mathrm{Kg}$ & $4 \times 105 / \mathrm{Kg}$ & $7 \times 107 / \mathrm{Kg}$ & $182 \times 105 / \mathrm{Kg}$ \\
\hline 2017 Anand & $\mathrm{nr}$ & $\mathrm{nr}$ & $1.5 \times 107 / \mathrm{Kg}$ & $\mathrm{nr}$ & $2.5 \times 107 / \mathrm{Kg}$ & $\mathrm{nr}$ & $4 \times 107 / \mathrm{Kg}$ & $\mathrm{nr}$ \\
\hline 2018 Stiff & $\begin{array}{l}401.5(0- \\
764)\end{array}$ & $\begin{array}{l}90(6- \\
398)\end{array}$ & $\mathrm{nr}$ & $\mathrm{nr}$ & $\mathrm{nr}$ & $\mathrm{nr}$ & $3.06 \times 107 / \mathrm{Kg}$ & $1.41 \times 105 / \mathrm{Kg}$ \\
\hline $\begin{array}{l}2018 \\
\text { Horwitz }\end{array}$ & 1.7 & 33 & $4.9 \times 107 / \mathrm{Kg}$ & $63 \times 105 / \mathrm{Kg}$ & - & - & $4.9 \times 107 / \mathrm{Kg}$ & $63 \times 105 / \mathrm{Kg}$ \\
\hline $\begin{array}{l}2013 \\
\text { Brunstein }\end{array}$ & - & - & $1.5 \times 107 / \mathrm{Kg}$ & $3.2 \times 105 / \mathrm{Kg}$ & $2.5 \times 107 / \mathrm{Kg}$ & $3.4 \times 105 / \mathrm{Kg}$ & $4 \times 107 / \mathrm{Kg}$ & $7.6 \times 105 / \mathrm{Kg}$ \\
\hline 2015 Popat & - & - & $1.75 \times 107 / \mathrm{Kg}$ & $0.92 \times 105 / \mathrm{Kg}$ & $2.59 \times 107 / \mathrm{Kg}$ & $1.15 \times 105 / \mathrm{Kg}$ & $4.26 \times 107 / \mathrm{Kg}$ & $2.37 \times 105 / \mathrm{Kg}$ \\
\hline 2013 Cutler & - & - & $1.8 \times 107 / \mathrm{Kg}$ & $0.74 \times 105 / \mathrm{Kg}$ & $1.7 \times 107 / \mathrm{Kg}$ & $0.56 \times 105 / \mathrm{Kg}$ & $3.5 \times 107 / \mathrm{Kg}$ & $2.37 \times 105 / \mathrm{Kg}$ \\
\hline
\end{tabular}

\section{Discussion}

As mentioned in mechanism, the molecules that acted on signal pathways of homing ability could also activate signal pathways of cell proliferation. Whereas this could not answer the question why the hematopoietic recovery was not accelerated among patients in expansion group, though they received even much more UCB cell dose than patients in incubation group. So a problem was brought into consideration, were the stem cells still "stem cells" after expansion? Sean J. Morrison et al [66] thought the goals of stem cells ex vivo expansion was to preserve the self-renewal ability while inhibit the differentiation tendency. Roberto et al [67] further indicated that in spite of being immunophenotipically similar, freshly isolated stem cells and ex vivo expanded stem cells showed significant differences both in functional and genetic terms. As a result, the long-term hematopoietic capacity of expanded stem cells may be impaired. As was known, the self-renewal, proliferation, differentiation, apoptosis, and bone marrow homing of stem cells were complex physiological processes that were hard to control by artificial regulation. Even the kind and dose of cytokines that should be used in different stem cell growth stage are diverse [68]. Given the fact that the most of the mechanisms behind stem cell proliferation remains unclear, it is hard to expand stem cells without losing their long-term hematopoietic capacity. Importantly, this have been confirmed in our included studies. Even the cell doses of expanded units were much higher than unmanipulated units, the predominance of donor cell engraftment were derived from unmanipulated UCB units rather than expanded units $[17,18]$. On the contrary, two incubation studies reported the predominance of long-term engraftments derived from manipulated UCB units [20, 23]. The third one had an opposite result but it was originally proven to be useless in accelerating hematopoietic recovery [19].

Bone marrow niches are vital to stem cells in hematopoietic transplantation for saving them from depletion while protecting the host from overexuberant stem-cell proliferation $[69,70]$. But not all of the infused donor stem cells could engraft into host bone marrow niche [71]. To this end, it 
is important to enhance the homing ability of infused stem cells. However, no better treatment effects were observed by injecting donor cells into recipient's BM niche directly [72-74]. Maybe it doesn't work unless the donor cells are "volunteered" rather than "forced" to go inside the niche. For example, activation of SDF-1a-CXCR4 axis could contribute to donor cells' volunteering [75-78]. In our included studies, homing ability of stem cells could be enhanced after a short-time incubation and the hematopoietic recovery was accelerated after transplantation. Treatment effects were almost the same compared to expansion studies even with much lower infused cell doses.

\section{Conclusion}

It is widely considered that the stem cell dose is vital for hematopoietic recovery during UCBT. As a result, expanding stem cell could be the first choice. But according to our analysis, expansion methods showed no significant improvement in treatment outcomes comparing to incubation methods, most possibly because the stem cells lost long-term hematopoietic capacity after ex vivo culture. In the meantime, expansion methods still took more resources, such as time and money, than incubation way. And they were also accompanied by the risks of contamination and culture failure.

It is believed that the goal of expanding stem cells while preserving their hematopoietic reconstitution ability can be achieved. Because more effective new molecules will be used in stem cell expansion manipulation with the further research of stem cells' physiological regulatory mechanisms and continuous optimization of in vitro culture system. However, there is still a long way to go.

\section{Declarations}

\section{Ethics approval and consent to participate}

Not applicable

\section{Consent for publication}

Not applicable

\section{Availability of data and materials}

The datasets used and/or analysed during the current study are available from the corresponding author on reasonable request

\section{Competing interests}

The authors declare that they have no competing interests.

\section{Funding}

This study was supported by the National Natural Science Foundation of China (no. 81670110).

\section{Authors' contributions}

Yang-Yang Lei, Shan-Hong Chang, and Wen-Ming Hua searched the relevant literature and clinical trials. Yang-Yang Lei, Lei Deng, Lu Wang, and Bin Rong collected and analyzed the data. Yang-Yang Lei, Ang Zhang, Mei Guo, Hui-Sheng Ai and Kai-Xun Hu were co-contributor in writing the manuscript. All authors read and approved the final manuscript.

\section{Acknowledgements}

Not applicable

\section{Authors' information (optional)}

Not applicable

\section{References}

1. Ballen KK, Gluckman E, Broxmeyer HE. Umbilical cord blood transplantation: the first 25 years and beyond. Blood. 2013;122(4):491-8.

2. Ooi J. Cord blood transplantation in adults. Bone Marrow Transplant. 2009;44(10):661-6.

3. Barker JN, Weisdorf DJ, DeFor TE, Blazar BR, McGlave PB, Miller JS, et al. Transplantation of 2 partially HLA-matched umbilical cord blood units to enhance engraftment in adults with hematologic malignancy. Blood. 2005;105(3):1343-7. 
4. Scaradavou A, Brunstein CG, Eapen M, Le-Rademacher J, Barker JN, Chao N, et al. Double unit grafts successfully extend the application of umbilical cord blood transplantation in adults with acute leukemia. Blood. 2013;121(5):752-8.

5. Horwitz ME, Frassoni F. Improving the outcome of umbilical cord blood transplantation through ex vivo expansion or graft manipulation. Cytotherapy. 2015;17(6):730-8.

6. Delaney C, Becker PS, Milano F, Nicoud I, Heimfeld S, Riffkin I, et al. Infusion of "off-the-shelf" Third Party Ex Vivo Expanded Cord Blood Progenitor Cells As Supportive Care Following Clofarabine with High Dose Cytarabine and Granulocyte Colony-Stimulating Factor Priming for the Treatment of AML. Blood. 2011;118(21):3640-

7. Milano F, Heimfeld S, Riffkin IB, Nicoud I, Appelbaum FR, Bernstein ID, et al. Infusion of a Non HLA-Matched Off-the-Shelf Ex Vivo Expanded Cord Blood Progenitor Cell Product Following Myeloablative Cord Blood Transplantation Is Safe, Decreases the Time to Hematopoietic Recovery, and Results in Excellent Overall Survival. Blood. 2014;124(21):46-.

8. Davis CC, Marti LC, Sempowski GD, Jeyaraj DA, Szabolcs P. Interleukin-7 permits Th1/Tc1 maturation and promotes ex vivo expansion of cord blood T cells: a critical step toward adoptive immunotherapy after cord blood transplantation. Cancer Res. 2010;70(13):5249-58.

9. Berglund S, Gertow J, Magalhaes I, Mattsson J, Uhlin M. Cord blood T cells cultured with IL-7 in addition to IL-2 exhibit a higher degree of polyfunctionality and superior proliferation potential. Journal of immunotherapy (Hagerstown, Md: 1997). $2013 ; 36(8): 432$ - 41.

10. Moher D, Liberati A, Tetzlaff J, Altman DG, Group P. Preferred reporting items for systematic reviews and meta-analyses: the PRISMA statement. BMJ. 2009;339:b2535.

11. Shpall EJ, Quinones R, Giller R, Zeng C, Baron AE, Jones RB, et al. Transplantation of ex vivo expanded cord blood. Biology of blood marrow transplantation: journal of the American Society for Blood Marrow Transplantation. 2002;8(7):368-76.

12. Stroup DF, Berlin JA, Morton SC, Olkin I, Williamson GD, Rennie D, et al. Meta-analysis of observational studies in epidemiology: a proposal for reporting. Meta-analysis Of Observational Studies in Epidemiology (MOOSE) group. Jama. 2000;283(15):2008-12.

13. Hozo SP, Djulbegovic B, Hozo I. Estimating the mean and variance from the median, range, and the size of a sample. BMC Med Res Methodol. 2005;5:13.

14. de Lima M, McMannis J, Komanduri K, Worth L, Karandish S, Jones R, et al. Randomized Study of Double Cord Blood Transplantation (CBT) with Versus without Ex-Vivo Expansion (EXP). Blood. 2007;110(11):2014-

15. de Lima M, McMannis J, Gee A, Komanduri K, Couriel D, Andersson BS, et al. Transplantation of ex vivo expanded cord blood cells using the copper chelator tetraethylenepentamine: a phase I/II clinical trial. Bone Marrow Transplant. 2008;41(9):771-8.

16. De Lima M, McMannis JD, Saliba R, Worth L, Kebriaei P, Popat U, et al. Double Cord Blood Transplantation (CBT) with and without Ex-Vivo Expansion (EXP): A Randomized, Controlled Study. Blood. 2008;112(11):154-.

17. Delaney C, Heimfeld S, Brashem-Stein C, Voorhies H, Manger RL, Bernstein ID. Notch-mediated expansion of human cord blood progenitor cells capable of rapid myeloid reconstitution. Nat Med. 2010;16(2):232-6.

18. de Lima M, McNiece I, Robinson SN, Munsell M, Eapen M, Horowitz M, et al. Cord-blood engraftment with ex vivo mesenchymal-cell coculture. N Engl J Med. 2012;367(24):2305-15.

19. Brunstein CG, McKenna DH, DeFor TE, Sumstad D, Paul P, Weisdorf DJ, et al. Complement fragment 3a priming of umbilical cord blood progenitors: safety profile. Biology of blood marrow transplantation: journal of the American Society for Blood Marrow Transplantation. 2013;19(10):1474-9.

20. Cutler C, Multani P, Robbins D, Kim HT, Le T, Hoggatt J, et al. Prostaglandin-modulated umbilical cord blood hematopoietic stem cell transplantation. Blood. 2013;122(17):3074-81.

21. Delaney C, Milano F, Nicoud I, Heimfeld S, Karanes C, Gutman JA, et al. Dose Dependent Enhancement Of Neutrophil Recovery By Infusion Of Notch Ligand Ex Vivo Expanded Cord Blood Progenitors: Results Of a Multi-Center Phase I Trial. Blood. 2013;122(21):297-.

22. Horwitz ME, Chao NJ, Rizzieri DA, Long GD, Sullivan KM, Gasparetto C, et al. Umbilical cord blood expansion with nicotinamide provides longterm multilineage engraftment. J Clin Invest. 2014;124(7):3121-8.

23. Popat U, Mehta RS, Rezvani K, Fox P, Kondo K, Marin D, et al. Enforced fucosylation of cord blood hematopoietic cells accelerates neutrophil and platelet engraftment after transplantation. Blood. 2015;125(19):2885-92.

24. Wagner JE Jr, Brunstein CG, Boitano AE, DeFor TE, McKenna D, Sumstad D, et al. Phase I/II Trial of StemRegenin-1 Expanded Umbilical Cord Blood Hematopoietic Stem Cells Supports Testing as a Stand-Alone Graft. Cell Stem Cell. 2016;18(1):144-55.

25. Anand S, Thomas S, Hyslop T, Adcock J, Corbet K, Gasparetto C, et al. Transplantation of Ex Vivo Expanded Umbilical Cord Blood (NiCord) Decreases Early Infection and Hospitalization. Biol Blood Marrow Transplant. 2017;23(7):1151-7.

26. Horwitz ME, Wease S, Blackwell B, Valcarcel D, Frassoni F, Boelens JJ, et al. Phase I/II Study of Stem-Cell Transplantation Using a Single Cord Blood Unit Expanded Ex Vivo With Nicotinamide. Journal of clinical oncology: official journal of the American Society of Clinical Oncology. 2019;37(5):367-74. 
27. Stiff PJ, Montesinos P, Peled T, Landau E, Goudsmid NR, Mandel J, et al. Cohort-Controlled Comparison of Umbilical Cord Blood Transplantation Using Carlecortemcel-L, a Single Progenitor-Enriched Cord Blood, to Double Cord Blood Unit Transplantation. Biol Blood Marrow Transplant. 2018;24(7):1463-70.

28. Bachier CR, Gokmen E, Teale J, Lanzkron S, Childs C, Franklin W, et al. Ex-vivo expansion of bone marrow progenitor cells for hematopoietic reconstitution following high-dose chemotherapy for breast cancer. Experimental hematology. 1999;27(4):615-23.

29. McNiece I, Jones R, Bearman SI, Cagnoni P, Nieto Y, Franklin W, et al. Ex vivo expanded peripheral blood progenitor cells provide rapid neutrophil recovery after high-dose chemotherapy in patients with breast cancer. Blood. 2000;96(9):3001-7.

30. Boiron JM, Dazey B, Cailliot C, Launay B, Attal M, Mazurier F, et al. Large-scale expansion and transplantation of CD34(+) hematopoietic cells: in vitro and in vivo confirmation of neutropenia abrogation related to the expansion process without impairment of the long-term engraftment capacity. Transfusion. 2006;46(11):1934-42.

31. Dahlberg A, Delaney C, Bernstein ID. Ex vivo expansion of human hematopoietic stem and progenitor cells. Blood. 2011;117(23):6083-90.

32. Laughlin MJ, Barker J, Bambach B, Koc ON, Rizzieri DA, Wagner JE, et al. Hematopoietic engraftment and survival in adult recipients of umbilical-cord blood from unrelated donors. N Engl J Med. 2001;344(24):1815-22.

33. Wagner JE, Barker JN, DeFor TE, Baker KS, Blazar BR, Eide C, et al. Transplantation of unrelated donor umbilical cord blood in 102 patients with malignant and nonmalignant diseases: influence of CD34 cell dose and HLA disparity on treatment-related mortality and survival. Blood. 2002;100(5):1611-8.

34. Page KM, Zhang L, Mendizabal A, Wease S, Carter S, Gentry T, et al. Total colony-forming units are a strong, independent predictor of neutrophil and platelet engraftment after unrelated umbilical cord blood transplantation: a single-center analysis of 435 cord blood transplants. Biology of blood marrow transplantation: journal of the American Society for Blood Marrow Transplantation. 2011;17(9):136274.

35. Kiernan J, Damien P, Monaghan M, Shorr R, Mclntyre L, Fergusson D, et al. Clinical Studies of Ex Vivo Expansion to Accelerate Engraftment After Umbilical Cord Blood Transplantation: A Systematic Review. Transfus Med Rev. 2017;31(3):173-82.

36. Butko E, Pouget C, Traver D. Complex regulation of HSC emergence by the Notch signaling pathway. Dev Biol. 2016;409(1):129-38.

37. Carlesso N, Aster JC, Sklar J, Scadden DT. Notch1-induced delay of human hematopoietic progenitor cell differentiation is associated with altered cell cycle kinetics. Blood. 1999;93(3):838-48.

38. Varnum-Finney B, Xu L, Brashem-Stein C, Nourigat C, Flowers D, Bakkour S, et al. Pluripotent, cytokine-dependent, hematopoietic stem cells are immortalized by constitutive Notch1 signaling. Nat Med. 2000;6(11):1278-81.

39. Kunisato A, Chiba S, Nakagami-Yamaguchi E, Kumano K, Saito T, Masuda S, et al. HES-1 preserves purified hematopoietic stem cells ex vivo and accumulates side population cells in vivo. Blood. 2003;101(5):1777-83.

40. Delaney C, Varnum-Finney B, Aoyama K, Brashem-Stein C, Bernstein ID. Dose-dependent effects of the Notch ligand Delta1 on ex vivo differentiation and in vivo marrow repopulating ability of cord blood cells. Blood. 2005;106(8):2693-9.

41. Varnum-Finney B, Wu L, Yu M, Brashem-Stein C, Staats S, Flowers D, et al. Immobilization of Notch ligand, Delta-1, is required for induction of notch signaling. Journal of cell science. 2000;113 Pt 23:4313-8.

42. McNiece I, Harrington J, Turney J, Kellner J, Shpall EJ. Ex vivo expansion of cord blood mononuclear cells on mesenchymal stem cells. Cytotherapy. 2004;6(4):311-7.

43. Robinson SN, Ng J, Niu T, Yang H, McMannis JD, Karandish S, et al. Superior ex vivo cord blood expansion following co-culture with bone marrow-derived mesenchymal stem cells. Bone Marrow Transplant. 2006;37(4):359-66.

44. Robinson SN, Simmons PJ, Yang H, Alousi AM, Marcos de Lima J, Shpall EJ. Mesenchymal stem cells in ex vivo cord blood expansion. Best Pract Res Clin Haematol. 2011;24(1):83-92.

45. Fajardo-Orduna GR, Mayani H, Montesinos JJ. Hematopoietic Support Capacity of Mesenchymal Stem Cells: Biology and Clinical Potential. Arch Med Res. 2015;46(8):589-96.

46. Jang YK, Jung DH, Jung MH, Kim DH, Yoo KH, Sung KW, et al. Mesenchymal stem cells feeder layer from human umbilical cord blood for ex vivo expanded growth and proliferation of hematopoietic progenitor cells. Ann Hematol. 2006;85(4):212-25.

47. Luan X, Li G, Wang G, Wang F, Lin Y. Human placenta-derived mesenchymal stem cells suppress T cell proliferation and support the culture expansion of cord blood CD34(+) cells: a comparison with human bone marrow-derived mesenchymal stem cells. Tissue Cell. 2013;45(1):32-8.

48. Boitano AE, Wang J, Romeo R, Bouchez LC, Parker AE, Sutton SE, et al. Aryl hydrocarbon receptor antagonists promote the expansion of human hematopoietic stem cells. Science. 2010;329(5997):1345-8.

49. Lindsey S, Papoutsakis ET. The evolving role of the aryl hydrocarbon receptor (AHR) in the normophysiology of hematopoiesis. Stem Cell Rev Rep. 2012;8(4):1223-35. 
50. Angelos MG, Ruh PN, Webber BR, Blum RH, Ryan CD, Bendzick L, et al. Aryl hydrocarbon receptor inhibition promotes hematolymphoid development from human pluripotent stem cells. Blood. 2017;129(26):3428-39.

51. Peled T, Landau E, Prus E, Treves AJ, Nagler A, Fibach E. Cellular copper content modulates differentiation and self-renewal in cultures of cord blood-derived CD34 + cells. Br J Haematol. 2002;116(3):655-61.

52. Peled T, Mandel J, Goudsmid RN, Landor C, Hasson N, Harati D, et al. Pre-clinical development of cord blood-derived progenitor cell graft expanded ex vivo with cytokines and the polyamine copper chelator tetraethylenepentamine. Cytotherapy. 2004;6(4):344-55.

53. Peled T, Landau E, Mandel J, Glukhman E, Goudsmid NR, Nagler A, et al. Linear polyamine copper chelator tetraethylenepentamine augments long-term ex vivo expansion of cord blood-derived CD34 + cells and increases their engraftment potential in NOD/SCID mice. Experimental hematology. 2004;32(6):547-55.

54. Huang X, Pierce LJ, Cobine PA, Winge DR, Spangrude GJ. Copper modulates the differentiation of mouse hematopoietic progenitor cells in culture. Cell Transplant. 2009;18(8):887-97.

55. Zarrabi M, Afzal E, Ebrahimi M. Manipulation of Hematopoietic Stem Cell Fate by Small Molecule Compounds. Stem Cells Dev. 2018;27(17):1175-90.

56. Peled T, Shoham H, Aschengrau D, Yackoubov D, Frei G, Rosenheimer GN, et al. Nicotinamide, a SIRT1 inhibitor, inhibits differentiation and facilitates expansion of hematopoietic progenitor cells with enhanced bone marrow homing and engraftment. Experimental hematology. 2012;40(4):342-55. e1.

57. North TE, Goessling W, Walkley CR, Lengerke C, Kopani KR, Lord AM, et al. Prostaglandin E2 regulates vertebrate haematopoietic stem cell homeostasis. Nature. 2007;447(7147):1007-11.

58. Hoggatt J, Singh P, Sampath J, Pelus LM. Prostaglandin E2 enhances hematopoietic stem cell homing, survival, and proliferation. Blood. 2009;113(22):5444-55.

59. Pelus LM, Hoggatt J, Singh P. Pulse exposure of haematopoietic grafts to prostaglandin E2 in vitro facilitates engraftment and recovery. Cell Prolif. 2011;44(Suppl 1):22-9.

60. Goessling W, Allen RS, Guan X, Jin P, Uchida N, Dovey M, et al. Prostaglandin E2 enhances human cord blood stem cell xenotransplants and shows long-term safety in preclinical nonhuman primate transplant models. Cell Stem Cell. 2011;8(4):445-58.

61. Reca R, Mastellos D, Majka M, Marquez L, Ratajczak J, Franchini S, et al. Functional receptor for C3a anaphylatoxin is expressed by normal hematopoietic stem/progenitor cells, and C3a enhances their homing-related responses to SDF-1. Blood. 2003;101(10):3784-93.

62. Ratajczak J, Reca R, Kucia M, Majka M, Allendorf DJ, Baran JT, et al. Mobilization studies in mice deficient in either C3 or C3a receptor (C3aR) reveal a novel role for complement in retention of hematopoietic stem/progenitor cells in bone marrow. Blood. 2004;103(6):2071-8.

63. Xia L, McDaniel JM, Yago T, Doeden A, McEver RP. Surface fucosylation of human cord blood cells augments binding to P-selectin and Eselectin and enhances engraftment in bone marrow. Blood. 2004;104(10):3091-6.

64. Robinson SN, Thomas MW, Simmons PJ, Lu J, Yang H, Parmar S, et al. Fucosylation with fucosyltransferase VI or fucosyltransferase VII improves cord blood engraftment. Cytotherapy. 2014;16(1):84-9.

65. Robinson SN, Thomas MW, Simmons PJ, Lu J, Yang H, Javni JA, et al. Non-fucosylated CB CD34(+) cells represent a good target for enforced fucosylation to improve engraftment following cord blood transplantation. Cytotherapy. 2017;19(2):285-92.

66. Morrison SJ, Kimble J. Asymmetric and symmetric stem-cell divisions in development and cancer. Nature. 2006;441(7097):1068-74.

67. Dircio-Maldonado R, Flores-Guzman P, Corral-Navarro J, Mondragon-Garcia I, Hidalgo-Miranda A, Beltran-Anaya FO, et al. Functional Integrity and Gene Expression Profiles of Human Cord Blood-Derived Hematopoietic Stem and Progenitor Cells Generated In Vitro. Stem Cells Transl Med. 2018;7(8):602-14.

68. Metcalf D. Hematopoietic cytokines. Blood. 2008;111(2):485-91.

69. Scadden DT. The stem-cell niche as an entity of action. Nature. 2006;441(7097):1075-9.

70. Morrison SJ, Spradling AC. Stem cells and niches: mechanisms that promote stem cell maintenance throughout life. Cell. 2008;132(4):598611.

71. Heazlewood SY, Oteiza A, Cao H, Nilsson SK. Analyzing hematopoietic stem cell homing, lodgment, and engraftment to better understand the bone marrow niche. Ann N Y Acad Sci. 2014;1310:119-28.

72. Brunstein CG, Barker JN, Weisdorf DJ, Defor TE, McKenna D, Chong SY, et al. Intra-BM injection to enhance engraftment after myeloablative umbilical cord blood transplantation with two partially HLA-matched units. Bone Marrow Transplant. 2009;43(12):935-40.

73. van Os R, Ausema A, Dontje B, van Riezen M, van Dam G, de Haan G. Engraftment of syngeneic bone marrow is not more efficient after intrafemoral transplantation than after traditional intravenous administration. Experimental hematology. 2010;38(11):1115-23.

74. Frassoni F, Varaldo R, Gualandi F, Bacigalupo A, Sambuceti G, Sacchi N, et al. The intra-bone marrow injection of cord blood cells extends the possibility of transplantation to the majority of patients with malignant hematopoietic diseases. Best Pract Res Clin Haematol. 2010;23(2):237-44. 
75. Christopherson KW 2nd, Hangoc G, Broxmeyer HE. Cell surface peptidase CD26/dipeptidylpeptidase IV regulates CXCL12/stromal cellderived factor-1 alpha-mediated chemotaxis of human cord blood CD34 + progenitor cells. J Immunol. 2002;169(12):7000-8.

76. Christopherson KW 2nd, Hangoc G, Mantel CR, Broxmeyer HE. Modulation of hematopoietic stem cell homing and engraftment by CD26. Science. 2004;305(5686):1000-3.

77. Farag SS, Srivastava S, Messina-Graham S, Schwartz J, Robertson MJ, Abonour R, et al. In vivo DPP-4 inhibition to enhance engraftment of single-unit cord blood transplants in adults with hematological malignancies. Stem Cells Dev. 2013;22(7):1007-15.

78. Velez de Mendizabal N, Strother RM, Farag SS, Broxmeyer HE, Messina-Graham S, Chitnis SD, et al. Modelling the sitagliptin effect on dipeptidyl peptidase-4 activity in adults with haematological malignancies after umbilical cord blood haematopoietic cell transplantation. Clin Pharmacokinet. 2014;53(3):247-59.

79. Fares I, Chagraoui J, Lehnertz B, MacRae T, Mayotte N, Tomellini E, et al. EPCR expression marks UM171-expanded CD34(+) cord blood stem cells. Blood. 2017;129(25):3344-51.

80. Fares I, Chagraoui J, Gareau Y, Gingras S, Ruel R, Mayotte N, et al. Cord blood expansion. Pyrimidoindole derivatives are agonists of human hematopoietic stem cell self-renewal. Science. 2014;345(6203):1509-12.

\section{Figures}

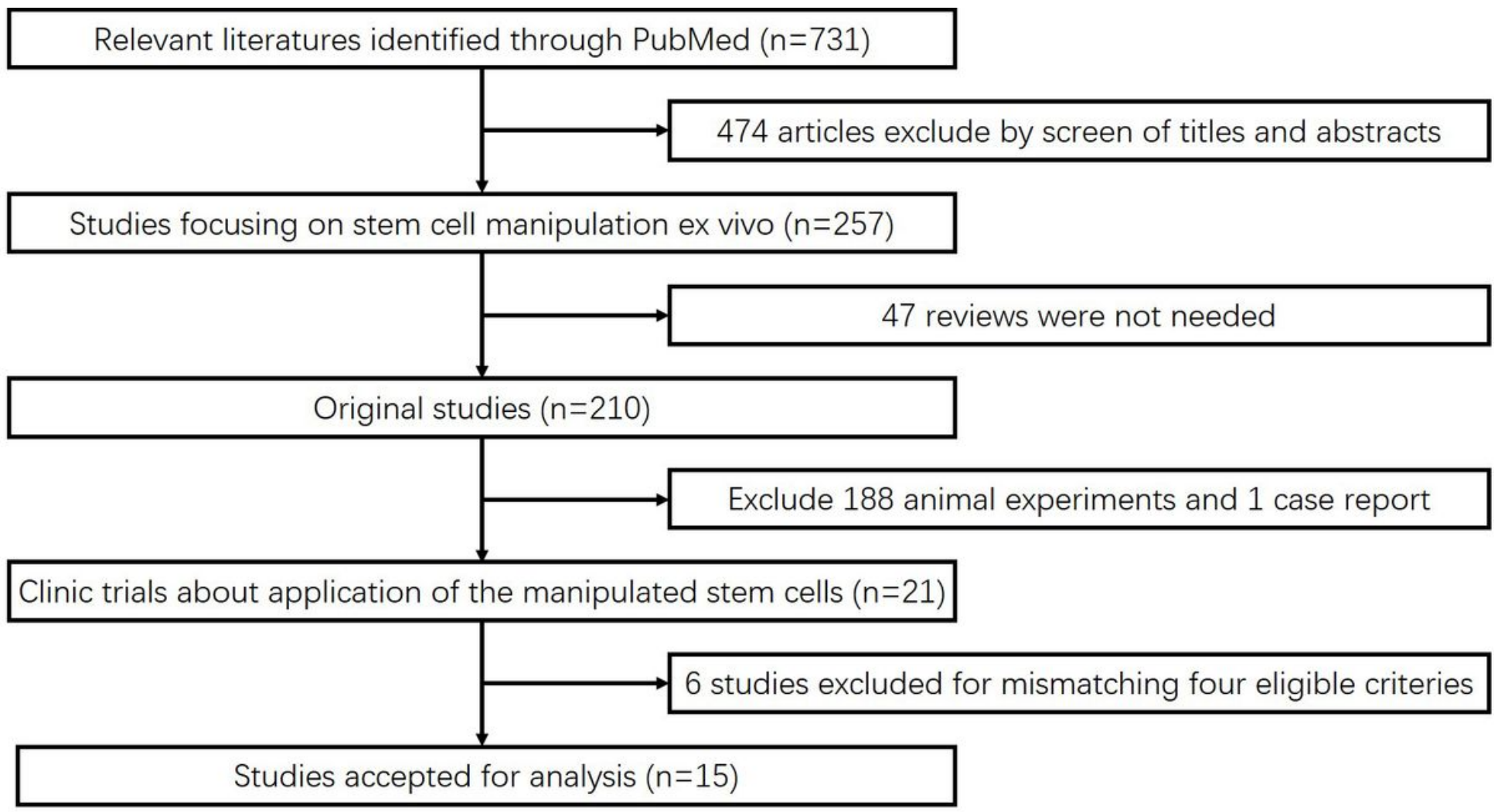

Figure 1

Flow of the search strategy. 


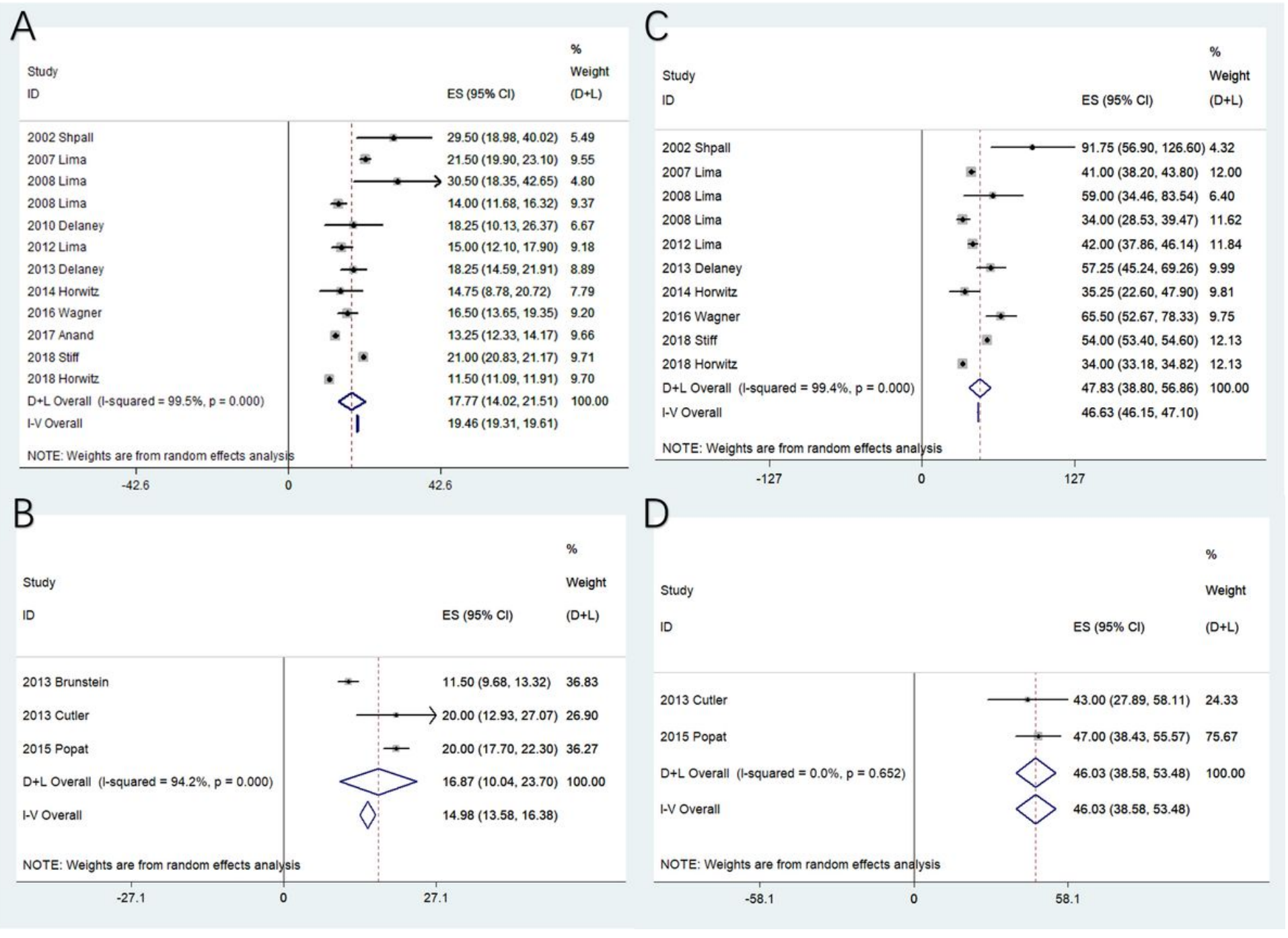

\section{Figure 2}

$A$ and $B$ were forest plots of neutrophil recovery time in expansion group and incubation group, respectively. $C$ and $D$ were forest plots of platelet recovery time in expansion group and incubation group, respectively. 


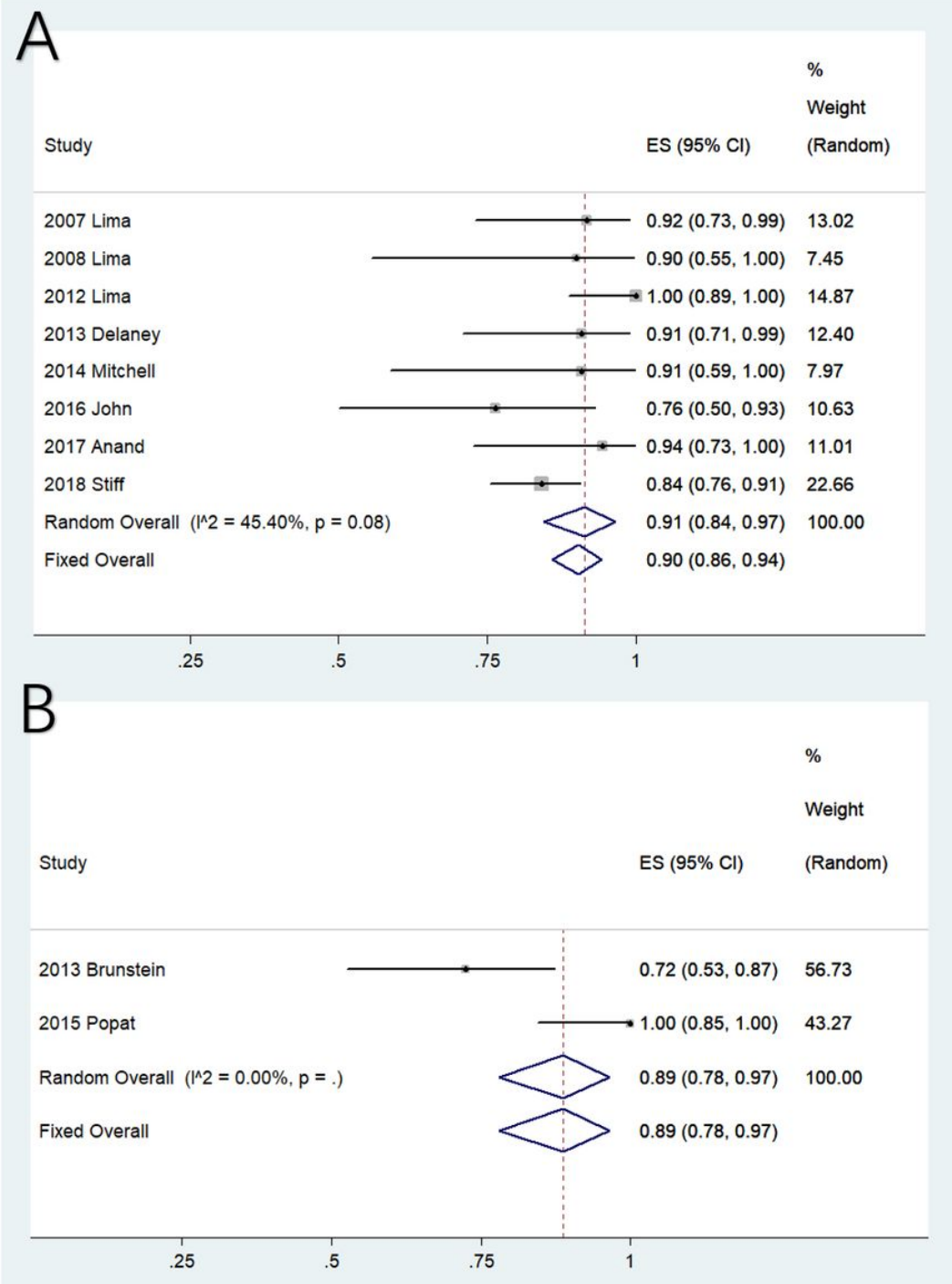

Figure 3

Forest plots of 100-day survival in expansion (A) and incubation (B) group. 


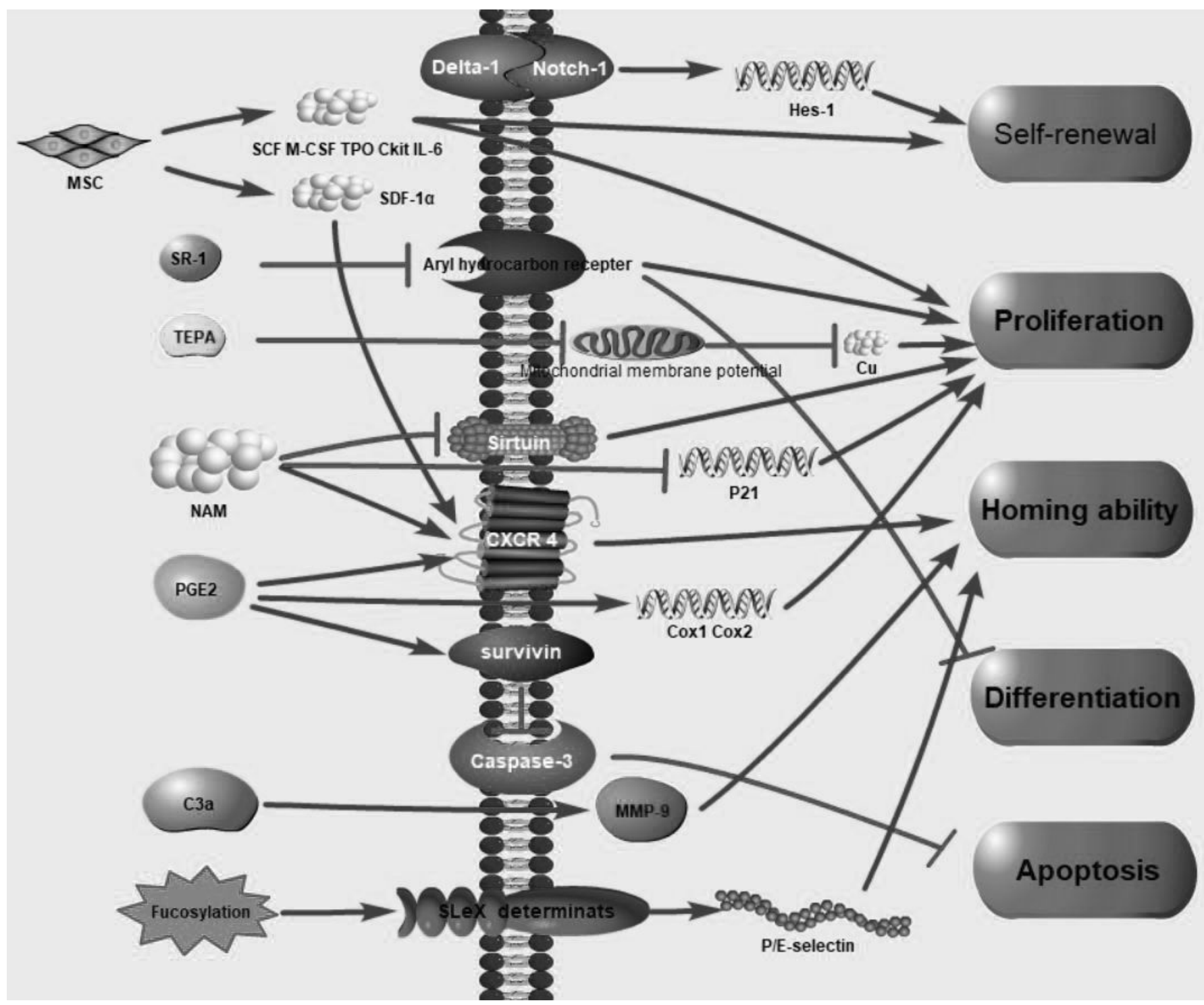

Figure 4

Intrinsic and extrinsic signals that involved in umbilical cord blood stem cell manipulation procedures. 


\begin{tabular}{|c|c|c|}
\hline \multicolumn{3}{|l|}{ Study } \\
\hline 2002 Shpall & $\longrightarrow$ & $\begin{array}{l}\text { ES }(95 \% \mathrm{Cl}) \\
29.50(18.98,40.02)\end{array}$ \\
\hline 2007 Lima & $\longrightarrow$ & $23.74(16.70,30.78)$ \\
\hline 2008 Lima & $\longrightarrow$ & $25.09(18.61,31.57)$ \\
\hline 2008 Lima & $\longrightarrow$ & $21.77(15.50,28.04)$ \\
\hline 2010 Delaney & $\rightarrow$ & $21.03(15.58,26.47)$ \\
\hline 2012 Lima & $\rightarrow$ & $19.54(15.11,23.97)$ \\
\hline 2013 Delaney & $\rightarrow$ & $19.14(15.44,22.84)$ \\
\hline 2014 Horwitz & $\rightarrow$ & $18.59(15.18,22.00)$ \\
\hline 2016 Wagner & $\rightarrow$ & $18.18(15.26,21.10)$ \\
\hline 2017 Anand & $\rightarrow$ & $17.60(14.67,20.53)$ \\
\hline 2018 Stiff & $\rightarrow$ & $18.13(15.10,21.15)$ \\
\hline 2018 Horwitz & $\rightarrow$ & $17.77(14.02,21.51)$ \\
\hline-40 & & 40 \\
\hline \multicolumn{3}{|c|}{$B$} \\
\hline \multicolumn{3}{|l|}{ Study } \\
\hline ID & & ES $(95 \% \mathrm{Cl})$ \\
\hline 2002 Shpall & $\longrightarrow$ & $-91.75(56.90,126.60)$ \\
\hline 2007 Lima & 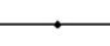 & $63.28(13.92,112.64)$ \\
\hline 2008 Lima & $\longrightarrow$ & $59.41(32.66,86.15)$ \\
\hline 2008 Lima & $\rightarrow$ & $43.93(33.98,53.88)$ \\
\hline 2012 Lima & $\rightarrow$ & $41.65(35.69,47.61)$ \\
\hline 2013 Delaney & $\rightarrow$ & $44.35(38.04,50.66)$ \\
\hline 2014 Horwitz & $\rightarrow$ & $43.15(37.38,48.92)$ \\
\hline 2016 Wagner & $\rightarrow$ & $46.45(39.98,52.92)$ \\
\hline 2018 Stiff & $\rightarrow$ & $48.66(41.26,56.06)$ \\
\hline 2018 Horwitz & $\rightarrow$ & $47.83(38.80,56.86)$ \\
\hline $\begin{array}{l}1 \\
-127\end{array}$ & & 127 \\
\hline
\end{tabular}

Figure 5

Cumulative meta-analysis of neutrophil (A) and platelet (B) recovery time of expansion group. 